日作紀（Jpn. J. Crop Sci.）81（3）：349-356（2012）

\title{
水稲品種「コシヒカリ」の高温登熟回避を目的とした 晚植条件下における密植栽培の評価
}

\author{
守田和弘 ${ }^{1)} \cdot$ 松島知昭 $^{2)} \cdot$ 山口环也 ${ }^{1)} \cdot$ 齋藤綾乃 $^{3)} \cdot$ 古畑昌巳 ${ }^{4)}$ \\ (1) 富山県農林水産総合技術センター, ${ }^{2)}$ 新川農林振興センター, ${ }^{3)}$ 富山県農業技術課, $\left.{ }^{4}\right)$ 中央農業総合研究センター北陸研究センター)
}

要旨：高温登熟回避を目的として晚植したコシヒカリにおいて, 密植栽培が生育, 収量および品質に及ぼす影響を調 查するとともに，晚植・密植栽培導入の有効性について評価した，その結果，穂数は栽植密度が高いほど多くなり， 収量は 18.2 株 $/ \mathrm{m}^{2}$ 区に比べて 21.2 株 $/ \mathrm{m}^{2}$ 区抢よび 24.2 株 $/ \mathrm{m}^{2}$ 区で高かった。また，登熟期間に日射量が少ない 年次に抢いては, 栽植密度が高いほど収量が増加した。外観品質は晚植・密植栽培を行うことで 2 ケ年を通して高水 準となり，登熟期間に日射量が多い年次でより整粒歩合が高かった。これらのことから，晚植条件下に拈ける密植栽 培は収量・品質の安定化に有効であり, 加えて, 登熟期間の高温を回避しつつ日射量を確保することが収量・品質の さらなる安定化に有効であることが示唆された。

キーワード：高温, コシヒカリ，栽植密度，収量，水稲，品質，

近年の温暖化の影響により，水稲作では基白粒，背白粒， 腹白粒, 心白粒, 乳白粒といった白未熟粒が多発するなど, 米の品質低下が全国的な問題となっている（寺島ら 2001, 井上 2003，森田 2005，松村 2006，高橋 2006，宮野·国分 2009). 白未熟粒の発生は登熟期間の高温が直接的な要因 とされることから（松村 2006, 森田 2008), その発生軽減 対策として高温登熟を回避する晚植が各地で励行され効果 をあげている（寺島ら 2001, 小葉田ら 2005). 富山県に扮 いては， 7 月下旬に出穂した水稲に比べ， 8 月上旬に出穂 した水稲は登熟気温の低下に起因する明らかな品質の向上 が認められたため (高橋 2006), 2003 年から移植時期を 1 ２週間程度遅らせる取組みを実施している(第 1 表)。そ の結果, 1998 年から 2002 年までの 1 等米比率が $87 \%$, $75 \% ， 74 \% ， 66 \% ， 55 \%$ と低下傾向であったのに対して, 2003 年以降は白未熟粒や胴割粒といった高温登熟被害粒が 減少することにより 1 等米比率が $80 \%$ 代まで回復し, 安 定した品質の改善効果が認められている(第 8 表).

一方, 富山県に执いて晚植を行った一部の圃場では, 品 質は向上するものの, やや減収する場合がみられ問題と なっている (守田ら 2011). 従来から, 水稲の移植栽培で は晚植することで減収となりやすいことが知られており， その要因として穂数の減少による $\mathrm{m}^{2}$ 当たり籾数の減少が 指摘されている (中谷 1972 , 伊藤・田中 1977, 楠谷ら 1992, 上田ら 1998a, b, 山口ら 2004)。このことは, 高温 登熟回避を目的とした晚植栽培は品質向上に寄与するもの の, 水稲の作期移動による気象的・生理的変動が生育や収 量にも影響を及ぼすことを示唆している。 そのため, 晚植 栽培を導入する場合には品質以外の要素も十分に検討する ことが必要であるものの, 高温登熟回避を目的とした晚植 栽培に対して品質以外の要素を検討した事例は少ない.

著者ら（2011）は前報に㧈いて, 高温登熟回避を目的と
した晚植栽培が生育, 収量, 品質に及ぼす影響を早植栽培 を対照として比較した結果, 晚植によって高温登熟を回避 できた場合, 品質は向上するものの, 穂数の減少により減 収となりやすいことを確認した。 また，各移植時期におい て栽植密度と収量, 品質との関係を検討した結果, 晚植栽 培では晚植による穂数の減少を補うために栽植密度を高め ることが有効であった，さらに，栽植密度を高めるほど穂 数増加, 収量増加につながるとともに, 外観品質が向上す ることを明らかにし, 高温登熟回避を目的とした晚植栽培 では密植栽培が有効となる可能性を示唆した.

しかしながら，一般に密植栽培は慣行栽培に比べて苗を 多く必要とするばかりでなく, 栽植密度が高すぎた場合に は過繁茂による玄米品質の低下（高橋ら 2004）や 1 穂籾数

第 1 表 富山県に扔ける水稲の移植時期と栽植密度.

\begin{tabular}{cclcc}
\hline \multirow{2}{*}{ 年次 } & 移植時期 & \multicolumn{3}{c}{ 栽植密度 $\left(\right.$ 株 $\left./ \mathrm{m}^{2}\right)$} \\
\cline { 3 - 5 } & 月 / 日 $)$ & \multicolumn{1}{c}{ 平均 } & 最高 & 最低 \\
\hline 1999 & $5 / 2$ & 21.3 & & \\
2000 & $5 / 3$ & 20.5 & & \\
2001 & $5 / 3$ & 21.0 & & \\
2002 & $5 / 3$ & 20.4 & & \\
2003 & $5 / 10$ & 19.7 & & \\
2004 & $5 / 8$ & 19.0 & & \\
2005 & $5 / 13$ & $18.7 \pm 1.5$ & 21.8 & 17.1 \\
2006 & $5 / 14$ & $19.0 \pm 1.4$ & 22.5 & 17.1 \\
2007 & $5 / 12$ & $18.8 \pm 1.5$ & 23.1 & 17.2 \\
2008 & $5 / 11$ & $19.8 \pm 1.6$ & 23.1 & 17.7 \\
2009 & $5 / 11$ & $19.5 \pm 1.6$ & 22.6 & 17.8 \\
2010 & $5 / 14$ & $20.1 \pm 2.0$ & 23.5 & 16.3 \\
\hline
\end{tabular}

移植時期は北陸農政局が公表している富山県のデー夕。栽植密度は 富山県内の農林振興センターが県内に設置する生育観測戋で得られ たデータ. 表中の数值は平均值 \pm 標準偏差を表す. 
第 2 表 月別気象概況.

\begin{tabular}{|c|c|c|c|c|c|c|c|c|}
\hline & \multirow{2}{*}{ 年次 } & \multirow{2}{*}{5 月 } & \multirow{2}{*}{6 月 } & \multirow{2}{*}{7 月 } & \multirow{2}{*}{8 月 } & \multirow{2}{*}{9 月 } & \multicolumn{2}{|c|}{ 出穂後（日） } \\
\hline & & & & & & & $1-20$ & $21-40$ \\
\hline \multirow{3}{*}{$\begin{array}{c}\text { 日平均気温 } \\
\left({ }^{\circ} \mathrm{C}\right)\end{array}$} & 2007 & 17.5 & 21.4 & 23.3 & 28.1 & 24.7 & 27.0 & 25.8 \\
\hline & 2008 & 17.7 & 20.4 & 26.8 & 26.2 & 22.7 & 25.7 & 24.5 \\
\hline & 平年值 & 16.7 & 20.6 & 24.6 & 26.1 & 21.8 & - & - \\
\hline \multirow{3}{*}{$\begin{array}{c}\text { 日射量 } \\
\left(\mathrm{MJ} / \mathrm{m}^{2} / \text { 日) }\right.\end{array}$} & 2007 & 18.8 & 16.1 & 11.9 & 19.6 & 13.9 & 17.0 & 15.1 \\
\hline & 2008 & 19.1 & 17.4 & 19.5 & 17.0 & 13.5 & 15.8 & 15.7 \\
\hline & 平年值 & 17.7 & 16.2 & 16.3 & 17.1 & 12.5 & - & - \\
\hline
\end{tabular}

日平均気温䇽よび日射量の平年值は 1971 2000 年までの平均值で表す.

の減少による収量低下（若松ら 2004）を招くことも報告さ れていることから，密植栽培を導入する場合には，収量・ 品質面に扮ける安定性の評価が重要となる。

そこで本研究では, 高温登熟回避を目的とした晚植栽培 において, 富山県の慣行的な栽植密度 (平均 19.3 株 $/ \mathrm{m}^{2}$ （2003～2010 年)，第 1 表）よりも密植とした条件を設定し， 密植栽培が生育, 収量および品質に及ぼす影響を調査する とともに, 晚植・密植栽培導入の有効性について評価した。

\section{材料と方法}

試験は 2007 年および 2008 年の 2 ケ年, 富山県農林水産 総合技術センター農業研究所内圑場（富山市吉岡, 沖積砂 壤土）に扔いて行った。品種はコシヒカリを供試し，2 ケ 年とも播種後約 20 日の稚苗を 5 月 22 日に機械 (井関農機 製 PZ50）移植した．移植直後， 1 株 $3 \sim 4$ 本植となるよう 補植により調整した。施肥量 (成分量) は，2 ケ年とも基肥 として $\mathrm{N}: \mathrm{P}_{2} \mathrm{O}_{5}: \mathrm{K}_{2} \mathrm{O}=4.0: 6.7: 5.3 \mathrm{~g} / \mathrm{m}^{2}$, 穂肥として $\mathrm{N}$ : $\mathrm{P}_{2} \mathrm{O}_{5}: \mathrm{K}_{2} \mathrm{O}=3.0: 0.6: 3.0 \mathrm{~g} / \mathrm{m}^{2}$ (出穂前 15 日㧍よび出穂 前 7 日に半量ずつ) 施用した。栽植密度は, 田植え機の設定 により 24.2 株 $/ \mathrm{m}^{2}$ 区 (条間 $30 \mathrm{~cm} \times$ 株間 $13.8 \mathrm{~cm}$ ), 21.2 株 $/ \mathrm{m}^{2}$ 区 (条間 $30 \mathrm{~cm} \times$ 株間 $15.7 \mathrm{~cm}$ ), 18.2 株 $/ \mathrm{m}^{2}$ 区 (条 間 $30 \mathrm{~cm} \times$ 株間 $18.3 \mathrm{~cm})$ の 3 水準を設けた。実際の栽植 密度は設定密度 $24.2,21.2,18.2$ 株 $/ \mathrm{m}^{2}$ 区の順に, 2007 年は $24.9,22.2,19.9$ 株 $/ \mathrm{m}^{2}, 2008$ 年は $24.3,21.5$, 19.1 株 $/ \mathrm{m}^{2}$ であったが, 以下は設定密度を試験区名で示 す. 1 試験区の面積は約 $32 \mathrm{~m}^{2}, 2$ 反復で試験を実施した.

調査は分げつ盛期, 最高分げつ期, 幼穂形成期, 出穂期 に茎数および群落葉色, 成熟期に収量, 収量構成要素㧍よ び玄米外観品質について行った，最高分げつ期は経時的 (およそ 7 日㧍き) に茎数を調査して分げつ数が最多となっ た日とし, 幼穂形成期は主秙の幼穂長が $2 \mathrm{~mm}$ に達した日 とした，茎数は各試験区において平均的な生育を示した 12 株について調査し, 群落葉色は試験区の群落上を FHK 葉 色カラースケール（富士平工業社製）を用いて測定した。 収量および収量構成要素は, 成熟期に各試験区 12 株につ いて穂数を調査後，これに加え 1 区当たり 1 坪（約 3.3 $\left.\mathrm{m}^{2}\right)$ を別に刈り取り，それぞれ天日乾燥を行った。乾燥後, 穂数調査株について脱粒し, 1 穂籾数を算出した. 登熟歩
合は籾を脱ぷ後, 粒厚 $1.9 \mathrm{~mm}$ 以上の精玄米数をもとに算 出した. $\mathrm{m}^{2}$ 当たり籾数は $\mathrm{m}^{2}$ 当たり穂数に 1 穂籾数を乗じ て算出した，精玄米重拉よび千粒重は，1 坪分の株を脱穀 した粒厚 $1.9 \mathrm{~mm}$ 以上の精立米を用いて算出し, 水分含有 率 $15 \%$ に值を補正した。玄米外観品質の調査は蛯谷ら （2008）の方法に準じ, 粒厚 $1.9 \mathrm{~mm}$ 以上の精玄米につい て肉眼で整粒, 基白粒, 背白粒, 腹白粒, 乳白粒, 心白粒, その他粒（青未熟粒，奇形粒および茶米）のいずれかに分 類し，それぞれの粒数を調査粒数当たりの比率として評価 した，品質調査粒数は各試験区につき 200 粒を 2 反復, 計 400 粒について実施した。

気象デー夕について, 日平均気温抒よび全天日射量（以 下, 日射量) は気象庁の測定值（観測地点：富山（富山県富 山市，標高 $8.6 \mathrm{~m}$ ) ) を使用した.

\section{結果}

\section{1. 試験年次の気象概況と生育ステージ}

試験を実施した 2 ケ年の月別気象概況を第 2 表に示した. 日平均気温についてみると，2007年の 7 月を除き，ほぼ平 年並みか高く推移した。 また, 日射量についても，2007 年 の 7 月を除き, ほぼ平年並みか多く推移した。品質や収量 に影響を及ぼす気象要因として，出穂後 20 日間（以下，登 熟前期）抢よび出穂後 21〜40 日（以下，登熟後期）の日平 均気温拉よび日射量を 2007 年と 2008 年で比較すると, 日 平均気温は登熟前期, 後期ともに 2007 年が 2008 年に比べ て高く, 日射量は登熟前期は 2007 年が 2008 年に比べて多 く，登熟後期は同程度であった。

各年次に扔ける生育ステージとステージ間日数を第 3 表 に示した，ステージ間日数について 2007 年と 2008 年を比 較すると, 2007 年は 2008 年に比べて移植〜最高分げつ期 が 5 日短く, 最高分げつ期〜幼穂形成期が 8 日長く, 幼穂 形成期〜出穂期が 2 日長く, 登熟期間は同程度であった。 な扮, 栽植密度の違いによる生育ステージの差は認められ なかった。

\section{2. 栽植密度が晚植水稲の茎数と葉色の推移および分げ つに及ぼす影響}

茎数は, 2 ケ年ともに生育期間を通して栽植密度が高い 
第 3 表 生育ステージ.

\begin{tabular}{|c|c|c|c|c|c|c|c|c|c|c|c|}
\hline \multirow{2}{*}{ 年次 } & \multicolumn{11}{|c|}{ 生育ステージ (月／日） } \\
\hline & 移植 & & $\mathrm{I}$ & & II & & III & & IV & & $\mathrm{V}$ \\
\hline 2007 & $5 / 22$ & (24) & $6 / 15$ & (18) & $7 / 3$ & (18) & $7 / 21$ & $(23)$ & $8 / 13$ & $(40)$ & $9 / 22$ \\
\hline 2008 & $5 / 22$ & (26) & $6 / 17$ & (21) & $7 / 8$ & (10) & $7 / 18$ & $(21)$ & $8 / 8$ & $(40)$ & $9 / 17$ \\
\hline
\end{tabular}

I : 分げつ盛期, II : 最高分げつ期, III : 幼穂形成期, IV : 出穂期, V : 成熟期 (第 1,2 図も同様).（ ) は生育ステージ間の日数を示す.
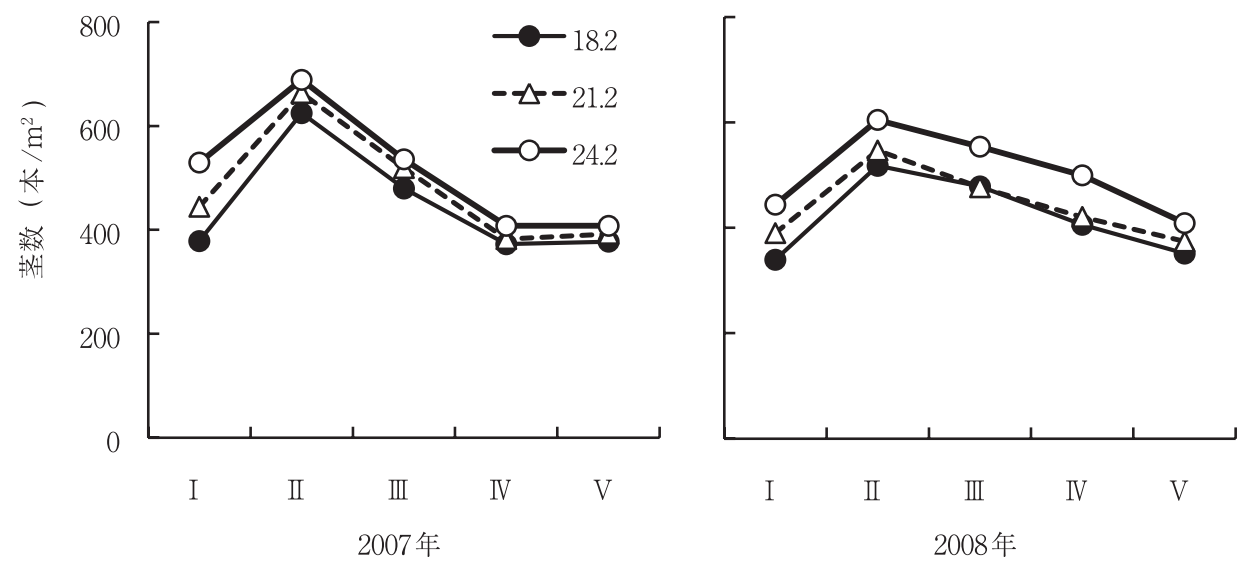

生育ステージ

第 1 図 栽植密度が茎数の推移に及ぼす影響.

生育ステージの表記は第 3 表に同じ。凡例は栽植密度 $\left(\right.$ 株 $\left./ \mathrm{m}^{2}\right)$.
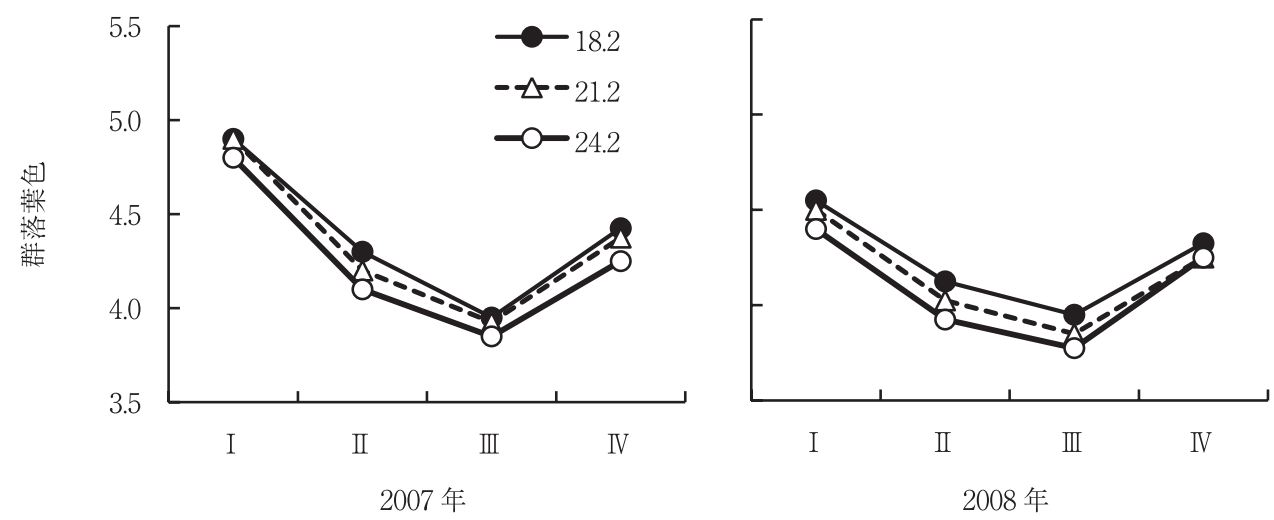

生育ステージ

第 2 図 栽植密度が葉色の推移に及ぼす影響.

生育ステージの表記は第 3 表に同じ，凡例は栽植密度 $\left(\right.$ 株 $\left./ \mathrm{m}^{2}\right)$. 群落葉色は試験区の群落上を

FHK 葉色カラースケール（富士平工業社製）を用いて測定した。

ほど多かった(第 1 図)。また, 葉色は栽植密度が高いほど 淡く推移した (第 2 図).

分げつの年次間差を比較すると, 2007 年は 2008 年に比 べて分げつ増加速度が速く, 最高分げつ数が多かったもの の, 穂数に有意な差は認められず, 有効茎歩合は有意に低 かった (第 4 表)。また, 栽植密度間で比較すると, 2 ケ年 とも栽植密度が高いほど分げつ増加速度が大きく, 最高分 げつ数が多い傾向はみられたものの, 穂数が有意に多いこ とから，有効茎歩合に差はみられなかった。

\section{3. 栽植密度が晚植水稲の収量および収量構成要素に及 ぼす影響}

収量㧍よび収量構成要素の年次間差を比較すると，千粒 重についてのみ有意な差が認められ，2007年に比べて 2008 年が大きかった (第 5 表)。一方, 栽植密度間では栽 植密度が高いほど穂数は多いものの, 1 穂籾数が少なく, この傾向は 2007 年に比べて 2008 年の方が大きかった。 ま た，登熟歩合は 21.2 株 $/ \mathrm{m}^{2}$ 区と 24.2 株 $/ \mathrm{m}^{2}$ 区に顕著な 差はみられないものの, 18.2 株 $/ \mathrm{m}^{2}$ 区は他の試験区より 
第 4 表＼cjkstart栽植密度が分げつに及ぼす影響

\begin{tabular}{cccccc}
\hline 年次 & $\begin{array}{c}\text { 栽植密度 } \\
\left(\text { 株 } / \mathrm{m}^{2}\right)\end{array}$ & $\begin{array}{c}\text { 分げつ増加速度 } \\
\left(\text { 本 } / \mathrm{m}^{2} / \text { 日 }\right)\end{array}$ & $\begin{array}{c}\text { 最高分げつ数 } \\
\left(\text { 本 } / \mathrm{m}^{2}\right)\end{array}$ & $\begin{array}{c}\text { 穂数 } \\
\left(\text { 本 } / \mathrm{m}^{2}\right)\end{array}$ & $\begin{array}{c}\text { 有効茎歩合 } \\
(\%)\end{array}$ \\
\hline \multirow{2}{*}{2007} & 18.2 & 14.9 & 625 & 377 & 60.4 \\
& 21.2 & 15.8 & 663 & 392 & 59.1 \\
2008 & 24.2 & 16.4 & 689 & 408 & 59.5 \\
\hline \multirow{2}{*}{20} & 11.0 & 518 & 351 & 68.3 \\
& 21.2 & 11.6 & 547 & 374 & 68.4 \\
分散分析 & 24.2 & 12.9 & 605 & 409 & 67.6 \\
& 年次 $(\mathrm{A})$ & $* *$ & $* *$ & $\mathrm{~ns}$ & $*$ \\
& 植密度 $(\mathrm{B})$ & $\mathrm{ns}$ & $\mathrm{ns}$ & $*$ & $\mathrm{~ns}$ \\
\hline & $\mathrm{A} \times \mathrm{B}$ & $\mathrm{ns}$ & $\mathrm{ns}$ & $\mathrm{ns}$ & $\mathrm{ns}$ \\
\hline
\end{tabular}

分げつ増加速度は移植〜最高分げつ期までの值。**は $1 \%$ 水準, *は $5 \%$ 水準で有意差があることを示す. ns：有意差なし，有効茎歩合は逆正弦変換した值を有意差検定した。

第 5 表＼cjkstart栽植密度が収量および収量構成要素に及ぼす影響.

\begin{tabular}{|c|c|c|c|c|c|c|c|}
\hline 年次 & $\begin{array}{l}\text { 栽植密度 } \\
\left(\text { 株 / } \mathrm{m}^{2}\right)\end{array}$ & $\begin{array}{c}\text { 精玄米重 } \\
\left(\mathrm{g} / \mathrm{m}^{2}\right)\end{array}$ & $\begin{array}{c}\text { 穂数 } \\
\left(\text { 本 } / \mathrm{m}^{2}\right)\end{array}$ & $\begin{array}{l}1 \text { 穂籵数 } \\
\text { (粒) }\end{array}$ & $\begin{array}{c}\text { 総籾数 } \\
\left(\times \text { 百粒 } / \mathrm{m}^{2}\right)\end{array}$ & $\begin{array}{c}\text { 登熟歩合 } \\
\text { (\%) }\end{array}$ & $\begin{array}{c}\text { 千粒重 } \\
(\mathrm{g})\end{array}$ \\
\hline \multirow{3}{*}{2007} & 18.2 & $477 \mathrm{a}$ & 377 a & $66.9 \mathrm{a}$ & 252 & 86.5 & 22.6 \\
\hline & 21.2 & $510 \mathrm{a}$ & 392 a & $66.5 \mathrm{a}$ & 261 & 87.8 & 22.5 \\
\hline & 24.2 & $504 \mathrm{a}$ & $408 \mathrm{a}$ & $62.4 \mathrm{a}$ & 255 & 87.6 & 22.5 \\
\hline \multirow{3}{*}{2008} & 18.2 & $468 \mathrm{a}$ & 351 a & $69.3 \mathrm{a}$ & 243 & 84.0 & 23.7 \\
\hline & 21.2 & $509 \mathrm{ab}$ & $374 \mathrm{ab}$ & $64.9 \mathrm{~b}$ & 243 & 87.3 & 24.1 \\
\hline & 24.2 & $534 \mathrm{~b}$ & $409 \mathrm{~b}$ & $62.8 \mathrm{~b}$ & 257 & 86.7 & 24.3 \\
\hline \multirow{3}{*}{ 分散分析 } & 年次 (A) & $\mathrm{ns}$ & ns & ns & ns & $\mathrm{ns}$ & $* *$ \\
\hline & 栽植密度 (B) & $*$ & $*$ & $*$ & ns & ns & ns \\
\hline & $\mathrm{A} \times \mathrm{B}$ & ns & ns & ns & ns & ns & ns \\
\hline
\end{tabular}

**は $1 \%$ 水準, *は $5 \%$ 水準で有意差があることを示す. ns : 有意差なし. 登熟歩合は逆正弦変換した值を有意差検 定した。同一英文字間は，各年次の栽植密度間に $5 \%$ 水準の有意差が無いことを示す (Tukey 法).

低い傾向が認められた。その結果，精玄米重は 2 ケ年とも 18.2 株 $/ \mathrm{m}^{2}$ 区と 21.2 株 $/ \mathrm{m}^{2}$ 区との間に有意差はみられ なかったものの, 2008 年は 18.2 株 $/ \mathrm{m}^{2}$ 区に比べて 24.2 株 $/ \mathrm{m}^{2}$ 区が有意に大きかった。

\section{4. 栽植密度が晚植水稲の外観品質に及ぼす影響}

品質の年次間差を比較すると， 2007 年は 2008 年に比べ て白未熟粒が有意に少なく，その他の未熟粒も少なかった 結果，整粒歩合は有意に高かった (第 6 表)。一方，栽植密 度間では品質に有意な差は認められなかった。

\section{考察}

前報（守田ら 2011）では，高温登熟回避を目的とした晚 植栽培が生育, 収量および品質に及ぼす影響について早植 栽培と比較した結果，晚植により登熟期間の高温を回避で きた場合に品質は向上するものの，穂数の減少により減収 となりやすいことを指摘した。また，その対応策として晚 植栽培では早植栽培に比べて栽植密度を高めることが収 量・品質の安定化に有効であることを示した。本研究では,
晚植栽培における密植栽培導入の有効性を評価する目的 で，密植栽培が生育，収量および品質に及ぼす影響につい て検討した。

\section{1. 密植栽培が晚植水稲の生育に及ぼす影響}

高温登熟回避を目的とした晚植栽培において，栽植密度 を富山県の慣行 (第 1 表) に対して, より密植とした条件 が生育に及ぼす影響を検討した結果，栽植密度を 24.2 株 $/ \mathrm{m}^{2}$ まで高めても茥数, 葉色の推移は前報（守田ら 2011） と同様の生育反応を示した。すなわち，2 ケ年を通して栽 植密度が高いほど分げつ増加速度が大きく，最高分げつ数 が多く，穂数も多いことから有効茥歩合に相違はみられず (第 4 表)，葉色は生育期間を通して栽植密度が高いほど淡 く推移した(第 2 図)

一方，年次間で生育を比較すると，2007 年に比べて 2008 年は初期の分げつ発生が緩慢となり, 最高分げつ数は 少なかった (第 4 表)，その後，2007 年は 7 月が低温寡照 で推移したため (第 2 表)，ラグ期が長期化 (第 3 表)する ことで有効茥歩合が低下し，穂数に有意な年次間差は認め 
第 6 表 栽植密度が外観品質に及ぼす影響.

\begin{tabular}{|c|c|c|c|c|c|c|c|c|c|}
\hline \multirow{3}{*}{ 年次 } & & & 白未熟 & & & & & & その他 \\
\hline & 栽植密度 & 整粒 & 合計 & 基白 & 背白 & 腹白 & 乳白 & 心白 & 未熟 \\
\hline & $\left(\right.$ 株 $\left./ \mathrm{m}^{2}\right)$ & $(\%)$ & (\%) & $(\%)$ & $(\%)$ & $(\%)$ & $(\%)$ & $(\%)$ & $(\%)$ \\
\hline \multirow{3}{*}{2007} & 18.2 & 82.8 & 6.3 & 0.0 & 0.0 & 1.0 & 0.8 & 4.5 & 11.0 \\
\hline & 21.2 & 83.8 & 5.3 & 0.0 & 0.0 & 1.0 & 1.8 & 2.5 & 11.0 \\
\hline & 24.2 & 79.3 & 7.8 & 0.0 & 0.3 & 0.8 & 1.8 & 5.0 & 13.0 \\
\hline \multirow{3}{*}{2008} & 18.2 & 74.5 & 13.0 & 1.3 & 0.3 & 4.3 & 2.5 & 4.8 & 12.5 \\
\hline & 21.2 & 75.0 & 10.5 & 0.0 & 0.8 & 3.5 & 1.5 & 4.8 & 14.5 \\
\hline & 24.2 & 75.0 & 11.3 & 1.3 & 0.3 & 2.0 & 1.8 & 6.0 & 13.8 \\
\hline \multirow{3}{*}{ 分散分析 } & 年次 (A) & $* *$ & $* *$ & ns & ns & $*$ & ns & ns & ns \\
\hline & 栽植密度（B） & ns & ns & ns & ns & ns & ns & ns & ns \\
\hline & $\mathrm{A} \times \mathrm{B}$ & ns & ns & ns & ns & ns & ns & ns & ns \\
\hline
\end{tabular}

**は $1 \%$ 水準,*は $5 \%$ 水準で有意差があることを示す. ns：有意差なし. 各数值は逆正弦変換した值を有意差検定した

られなかった．しかし，最高分げつ数が少なかった 2008 年においては栽植密度間の穂数の差が大きく(第 4 表), 栽 植密度を高く設定することにより 2007 年並みの穂数が確 保された。高温登熟回避を目的とした晚植栽培では, 早植 栽培に比べて初期茎数が確保しにくく穂数が減少しやすい ことから (守田ら 2011)，栽植密度を慣行以上に高めるこ とは穂数確保の観点からは有効であると考えられる.

\section{2. 密植栽培が晚植水稲の収量および収量構成要素に及 ぼす影響}

高温登熟回避を目的とした晚植栽培において, 密植条件 が収量および収量構成要素に及ぼす影響を検討した結果, 2 ケ年を通して栽植密度が高いほど穂数が多く, 1 穂籾数 は少なくなることから, 総籾数に差はないものの, 精玄米 重は 18.2 株 $/ \mathrm{m}^{2}$ 区に比べて 21.2 株 $/ \mathrm{m}^{2}$ 区および 24.2 株 $/ \mathrm{m}^{2}$ 区で高くなる傾向を示した. 18.2 株 $/ \mathrm{m}^{2}$ 区の減収 要因として登熟歩合の低下があげられるが(第 5 表), これ は穂数の減少に伴って 1 穂籾数が増加し, 登熟程度に劣る 弱勢頴果が増加したためと考えられる。弱勢頴果は初期の 発育が緩慢で登熟後期まで発育を続けるものの（木戸・梁 取 1968), 晚植栽培では登熟期間の日射量の低下が大きく, 弱勢頴果を中心とした登熟歩合の低下が特に生じやすいと 考えられる。これに関して, 若松ら（2004）は18２7株/ $\mathrm{m}^{2}$ の範囲において総籾数が同等でも疎植になるほど登熟歩 合は低下し，減収することを報告しており，守田ら (2011) も 15 21株 $/ \mathrm{m}^{2}$ の範囲に押いて同様の傾向を確認している.

一方, 精玄米重について, 2007 年では 21.2 株 $/ \mathrm{m}^{2}$ 区と 24.2 株 $/ \mathrm{m}^{2}$ 区に大差がみられないものの, 2008 年では 21.2 株 $/ \mathrm{m}^{2}$ 区に比べ 24.2 株 $/ \mathrm{m}^{2}$ 区で大きい傾向が認め られた (第 5 表)。これに関して, 2007 年は 2008 年に比べ て 21.2 株 $/ \mathrm{m}^{2}$ 区の穂数が多かったことに加え, 登熟前期 の日射量が多かったことから (第 2 表), 登熟条件が良好で あったと推察される。逆に, 2008 年は 2007 年に比べて 21.2 株 $/ \mathrm{m}^{2}$ 区と 24.2 株 $/ \mathrm{m}^{2}$ 区の穂数の差が大きく, 登
熟前期の日射量が少なかったため 24.2 株 $/ \mathrm{m}^{2}$ 区で収量が 高くなったものと考えられる。登熟期間の日射量と栽植密 度の関係に関して，早植などにおいて葉面積が十分に確保 される栽培条件では, 疎植が標準密度に比べて受光態勢の 改善により臭照の影響が小さくなるとする報告もある（井 上ら 2004). しかし, 本研究のように密植でも過繁茂とな りにくい晚植栽培においては, 受光効率よりも栽植密度を 高めて穂数・総籾数を確保するとともに, 弱勢頴果を制限 して登熟程度を高めることが収量の安定化には有効である と考えられた。

\section{3. 密植栽培が晚植水稲の品質に及ぼす影響}

高温登熟回避を目的とした晚植栽培において, 密植条件 が品質に及ぼす影響を検討した結果, 晚植を行うことによ り 2 ヶ年とも出穂後 20 日間の日平均気温が $27.0^{\circ} \mathrm{C}$ 以下で あったことから (第 2 表), 整粒歩合は安定して高かった(第 6 表)。前報 (守田ら 2011) に扔いて, 晚植栽培では栽植密 度を高めることで 1 穂籾数は減少し, 登熟程度に劣る弱勢 頴果が少なくなることにより品質が向上することを報告し たが, 本研究では栽植密度間の品質に顕著な差は認められ なかった，これは，2 ケ年ともに高温登熟が回避できたこ とに加え, 前報に比べて密植条件下における比較であり, いずれの試験区においても品質が安定して高かったためで あると推察される。

また, 前報（守田ら 2011）では，早植栽培において栽植 密度が高い場合, 過繁茂により生育期間中の葉色が大きく 低下し，それに伴い品質の低下が認められたが, 本研究で は栽植密度が高い 24.2 株 $/ \mathrm{m}^{2}$ であっても品質の低下は認 められなかった，登熟相の窒素栄養状態と密接に関係する 白未熟粒として基白・背白粒があげられるが（中川ら 2006, 若松ら 2008), 本研究では基白・背白粒の発生がほ とんど認められず, 栽植密度 24.2 株 $/ \mathrm{m}^{2}$ の範囲内では品 質に影響するほどの顕著な過繁茂や葉色の低下はなかった ものと推察される. 
一方，本研究における品質については，むしろ年次間の 影響が大きかった。これに関して，2008 年は 2007 年に比 べて登熟前期の日射量が少なかったことが要因の一つと考 えられる，登熟期間が寡照条件となった場合，乳白粒，心 白粒を中心とした白未熟粒が多発することが報告されてお り（長戸 1952，寺島ら 2001，坂田・高田 2006，若松ら 2009, 高田ら 2010), その発生に関して特に登熟前期の影 響が大きいことが指摘されている（小谷ら 2006，若松ら 2006）。本研究に打ける 2007 年と 2008 年の品質を比較す ると，登熟前期の日射量が少なかった 2008 年は，2007 年 に比べて腹白粒, 乳白粒, 心白粒, その他未熟粒の発生が 多く，それらを合わせた白未熟粒が有意に多かったことに より整粒歩合の低下が認められた (第 6 表)。このことから, 登熟期間が塞照となりやすい晚植栽培においては, 品質低 下をもたらさない範囲で高温を回避するとともに，可能な 限り日射量を確保できる移植時期を設定することが品質の 高位安定化に有効であると考えられた。

\section{4. 気象解析による晚植・密植栽培の有効性の検証}

本研究では晚植栽培における密植条件が生育・収量・品 質に及ぼす影響について 2 ケ年検討した結果，収量につい ては栽植密度の影響, 品質については年次の影響が大き かった。また，登熟期間の日射条件が収量・品質の大きな

第 7 表 登熟期間の気象条件と 1 等米比率および収量との相関係数.

\begin{tabular}{|c|c|c|c|}
\hline & \multirow{2}{*}{ 気象要素 } & \multicolumn{2}{|c|}{ 出穂後日数 } \\
\hline & & $1 \sim 20$ & $21 \sim 40$ \\
\hline 1 等米比率 & 日平均気温 $\left({ }^{\circ} \mathrm{C}\right)$ & $-0.58^{*}$ & -0.49 \\
\hline (\%) & 日射量 (MJ/m²/日) & -0.20 & $-0.66^{*}$ \\
\hline 収量 & 日平均気温 $\left({ }^{\circ} \mathrm{C}\right)$ & 0.37 & -0.05 \\
\hline$\left(\mathrm{g} / \mathrm{m}^{2}\right)$ & 日射量 (MJ/m²/ 日) & $0.64^{*}$ & 0.08 \\
\hline
\end{tabular}

1 等米比率および収量は北陸農政局が公表している 1999 2010 年に おける富山県のデー夕(第 $3 ， 4$ 図，第 8 表も同様）。登熟各期間の 気象值を積算し，1等米比率および収量との相関係数（r) を求めた. *: 5\%水準で有意.

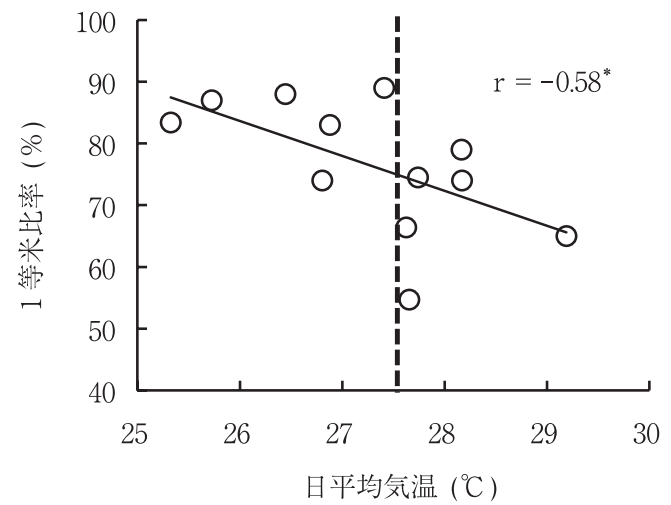

変動要因として考えられた。そこで, 本研究の結果を基に 富山県の過去のデータを用いて，晚植・密植栽培の効果を 気象面から解析するとともに，それを踏まえた今後の技術 構築について若干考察を行いたい.

富山県に㧈ける 1999 2010 年の登熟期間の気象条件と 1 等米比率および収量との関係を第 7 表に示した，登熟前期 において, 日平均気温と 1 等米比率に負の相関関係，日射 量と収量に正の相関関係が認められた。これは，高温登熟 回避のための晚植は品質を向上させるが，それに伴う日射 量の低下は収量低下をもたらすことを示唆している。また 登熟後期においては，日射量と 1 等米比率に負の相関関係 が認められた。これに関して，弱勢頴果は初期の発育が緩 慢で登熟後期まで発育を続けること（木戸・梁取 1968）, 未熟粒の発生は弱勢頴果に多いこと（森田 $2000 a, b$, 高橋 2006）から，登熟後期の日射量が多くなることにより弱勢 頴果の登熟程度が向上し，未熟粒の混入が増加することが 一つの要因と考えられる.

ここで, 収量・品質の両立を図る上で重要な期間と考え られた登熟前期の気象要因について解析するため，登熟前 期において高い相関関係が認められた日平均気温と 1 等米 比率，日射量と収量との関係を第 3 図に示した。富山県に おける過去のデー夕状況を鑑み， 1 等米比率と収量の許容 限界を 1 等米比率 $75 \%$, 収量 $530 \mathrm{~g} / \mathrm{m}^{2}$ と仮定した場合, これらを達成するための登熟前期の気象条件は， 1 等米比 率からは日平均気温 $27.5^{\circ} \mathrm{C}$ 未満, 収量加は日射量 16.7 $\mathrm{MJ} / \mathrm{m}^{2} /$ 日以上が導かれる。 そこで，これらの值を基準值 として，出穂後 20 日間の日平均気温 $27.5^{\circ} \mathrm{C}$ 以上を高温, 同 $27.5^{\circ} \mathrm{C}$ 未満を低温, 日射量 $16.7 \mathrm{MJ} / \mathrm{m}^{2} /$ 日以上を多照, 同 $16.7 \mathrm{MJ} / \mathrm{m}^{2}$ / 日未満を寡照として区分し，各年次にお ける登熟前期の気象条件と 1 等米比率㧍よび収量との関係 を第 4 図に示した。高温寡照条件 $(\times)$ では 1 等米比率・ 収量ともに低く, 高温多照条件 $(\triangle)$ では収量は高いもの の 1 等米比率が 55～ $80 \%$ と大きくふれており，低温寊照条 件 (O) および低温多照条件 $(\bigcirc)$ では 1 等米比率が両者と も安定して高いものの, 収量は $500 \sim 550 \mathrm{~g} / \mathrm{m}^{2}$ と大きくふ

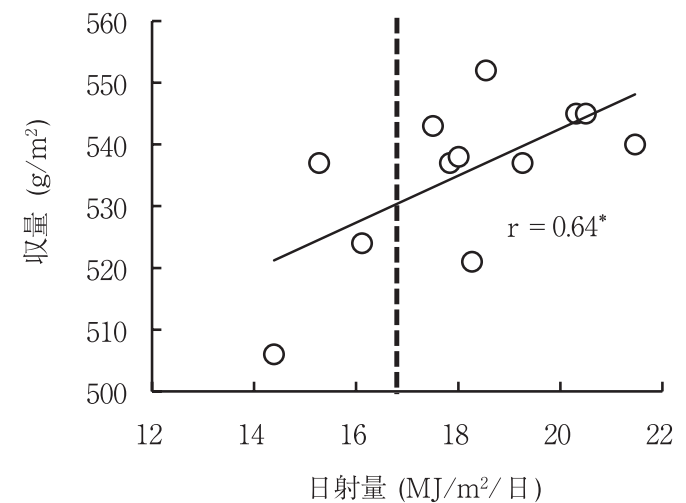

第 3 図 出穂後 20 日間の日平均気温と 1 等米比率との関係 (左図) および日射量と収量との関係 (右図). *: $5 \%$ 水準で有意. 


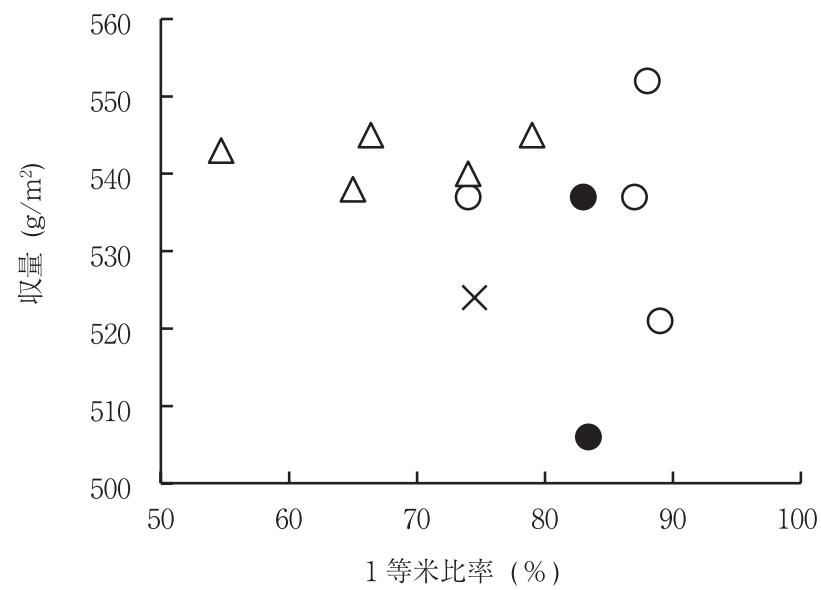

第 4 図 出穂後 20 日間の気象条件と 1 等米比率および収量との関係. 気象条件は基準值を日平均気温 $27.5^{\circ} \mathrm{C}$, 日射量 $16.7 \mathrm{MJ} / \mathrm{m}^{2} /$ 日とし， $\times: 27.5^{\circ} \mathrm{C}$ 以上 $\cdot 16.7 \mathrm{MJ} / \mathrm{m}^{2} /$ 日未満, $\triangle: 27.5^{\circ} \mathrm{C}$ 以上. $16.7 \mathrm{MJ} / \mathrm{m}^{2} /$ 日以上, $: 27.5^{\circ} \mathrm{C}$ 未満 $\cdot 16.7 \mathrm{MJ} / \mathrm{m}^{2} /$ 日未満, $\mathrm{O}: 27.5^{\circ} \mathrm{C}$ 未満 $\cdot 16.7 \mathrm{MJ} / \mathrm{m}^{2} /$ 日以上.

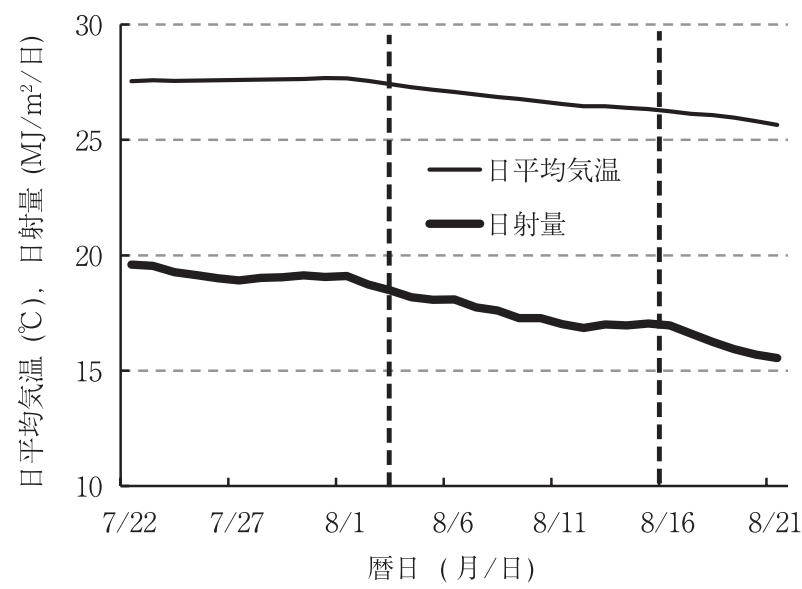

第 5 図富山県における登熟初期の気象推移.

気象デー夕は 1999 2010 年の測定值を使用し, 暦日を起点 とした 20 日間の平均值で示す。図中の点線は日平均気温 $27.5^{\circ} \mathrm{C}$ 未満, 日射量 $16.7 \mathrm{MJ} / \mathrm{m}^{2} /$ 日以上となる期間を示す.

れている。低温条件で比較すると，低温寡照 に比べ て低温多照（○）の方が 1 等米比率・収量ともにより高い 值を示した。低温条件における 1 等米比率の差は, 本研究 における 2007 年と 2008 年の品質の差をよく反映していた (第 2 表, 第 6 表)。また, 低温条件でみられた収量のふれは, 本研究のように栽植密度を高めることで安定させることが 可能と考えられ (第 5 表), 気象面からみても晚植 - 密植栽 培は品質・収量の安定化技術の一助となる可能性を示唆し ている。なお，本解析により導かれた基準值（日平均気温 $27.5^{\circ} \mathrm{C}$ ，日射量 $16.7 \mathrm{MJ} / \mathrm{m}^{2} /$ 日）は，富山市の気象值を 県内全域の代表值と仮定して行った結果であることを付記 しておく.

一方，富山県の近年 $(1999 \sim 2010$ 年) の気象データから,
第 8 表 富山県における水稲の出穂期, 収量および 1 等米比率

\begin{tabular}{cccc}
\hline 年次 & $\begin{array}{c}\text { 出穂期 } \\
\text { 月 / 日 })\end{array}$ & $\begin{array}{c}\text { 収量 } \\
\left(\mathrm{g} / \mathrm{m}^{2}\right)\end{array}$ & $\begin{array}{c}\text { 1 等米比率 } \\
(\%)\end{array}$ \\
\hline 1999 & $\mathbf{8 / 4}$ & 524 & $\mathbf{7 5}$ \\
2000 & $7 / 29$ & $\mathbf{5 4 0}$ & 74 \\
2001 & $7 / 28$ & $\mathbf{5 4 5}$ & 66 \\
2002 & $8 / 1$ & $\mathbf{5 4 3}$ & 55 \\
2003 & $\mathbf{8 / 9}$ & 506 & $\mathbf{8 3}$ \\
2004 & $8 / 2$ & $\mathbf{5 3 7}$ & 73 \\
2005 & $\mathbf{8 / 4}$ & $\mathbf{5 3 7}$ & $\mathbf{8 2}$ \\
2006 & $\mathbf{8} / \mathbf{8}$ & $\mathbf{5 4 5}$ & $\mathbf{8 0}$ \\
2007 & $\mathbf{8 / 1 1}$ & 521 & $\mathbf{8 9}$ \\
2008 & $\mathbf{8} / \mathbf{3}$ & $\mathbf{5 5 2}$ & $\mathbf{8 8}$ \\
2009 & $\mathbf{8 / ~}$ & $\mathbf{5 3 7}$ & $\mathbf{8 7}$ \\
2010 & $\mathbf{8 / 5}$ & $\mathbf{5 3 8}$ & 65 \\
\hline
\end{tabular}

太字は, 出穂期が $8 / 3 \sim 8 / 16$, 収量 $530 \mathrm{~g} / \mathrm{m}^{2}$ 以上, 1 等米比率 $75 \%$ 以上であることを示す。

登熟前期の日平均気温 $27.5^{\circ} \mathrm{C}$ 未満, 日射量 $16.7 \mathrm{MJ} / \mathrm{m}^{2} /$ 日以上となる期間を概算すると, 日平均気温による制限と して $8 / 3$ 以降, 日射量による制限として $8 / 16$ 以前が導か れる (第 5 図)。富山県が移植時期の繰り下げに取組んだ 2003 年以降 (第 1 表), 出穂期はほぼこの期間 $(8 / 3 \sim 8 / 16)$ に収まっており，1等米比率は安定して高い傾向を示すも のの，2007 年のように出穂期が遅い場合は収量が低くなる 傾向が確認できる (第 8 表)。さらに, 富山県の平均的な出 穂期である 8 月上旬は日平均気温の低下に比べて日射量の 低下が大きくなっており (第 5 図), 高温寡照が特に生じゃ すい時期と考えられる。全国的にも今後さらなる高温寡照 傾向の進行が予想されていることから（河津ら 2007）, 高 温寡照に対する技術対策として, 栽植密度と合わせて施肥 法や耐性品種等について, 今後さらに検討する必要がある。

謝辞：本研究の遂行に当たり，富山県農林水産総合技術 センター農業研究所栽培課スタッフの皆さんには大変ご協 力いただいた。ここに記して感謝の意を表します。

\section{引用文献}

蛯谷武志 - 山本良孝 . 矢野昌裕 - 舟根政治 2008. 染色体断片置換系 統群を利用したイネの玄米外観品質に関与するQTLの検出. 育種 学研究 $10: 91-99$.

井上健一 2003. 高温のイネ生産への影響と技術的対策 - 福井県の場 合一.日作紀 72 (別 2) : 440-445.

井上健一 - 林恒夫 ·湯浅佳織 ·笈田豊彦 2004. 水稲品質食味要因の 安定性に関する解析的研究 2 . 疎植条件が水稲の物質生産と収量品 質に及ぼす影響. 福井農試研報 $41: 15-28$.

伊藤十四英・田中孝幸 1977. 水稲の幼苗および成苗における作期の 移動が収量生産過程に及ぼす影響. 北陸作報 $12: 14-17$.

河津俊作 ·本間香貴 · 堀江武 · 白岩立彦 2007. 近年の日本における 稲作気象の变化とその水稲収量 - 外観品質への影響. 日作紀 76 : $423-432$. 
木戸三夫 ·梁取昭三 1968. 腹白, 基白, 心白状乳白, 乳白米の穂上にお ける着粒位置と不透明部のかたちに関する研究. 日作紀 $37: 534-$ 538.

小葉田亨 · 月森弘 · 井上健一 · 寺島一男 - 飯田幸彦 2005. 温暖化す る気象条件下での早期栽培イネにおける品質・収量低下に対する 技術的対応. 日作紀 $74: 80-93$.

小谷俊之. 松村洋一. 黒田晃 2006 . 出穂前後の遮光処理が水稲品種「ゆ めみずほ」の収量および品質に及ぼす影響. 石川農総研研報 $27: 1$ $-9$.

楠谷彰人 ·浅沼興一郎·木暮秩・関学 ·平田壮太郎 · 柳原哲司 1992. 暖地における早期栽培水稲品種キヌヒカリの収量および食 味. 日作紀 $61: 603-609$.

松村修 2006. 高温登熟性を向上する. 農及園 81 (1) : 96-101.

宮野法近・国分牧衛 2009. 宮城県に扔ける水稲玄米品質低下要因の

解析 - 気象要因の影響について - . 日作紀 $78: 225-233$.

森田敏 2000a. 高温が水稲の登熟に及ぼす影響－人工気象室における 温度処理実験による解析一.日作紀 $69: 391-399$.

森田敏 2000b. 高温が水稲の登熟に及ぼす影響－作期移動実験と標高 の異なる地点へのポット移動実験による解析一. 日作紀 $69: 400-$ 405.

森田敏 2005. 水稲の登熟期の高温によって発生する白未熟粒, 充実不 足抢よび粒重低下. 農業技術 $60: 442-446$.

森田敏 2008. イネの高温登熟障害の克服に向けて. 日作紀 $77: 1-12$. 守田和弘・高橋涉・杉森史郎・古畑昌巳 2011. 富山県に打ける水稲 品種「コシヒカリ」の高温登熟回避を目的とした晚植栽培に適し た栽植密度. 日作紀 $80: 220-228$.

長戸一雄 1952. 心白 ·乳白米及び腹白の発生に関する研究. 日作紀 $21: 26-28$.

中川博視 · 白川美翠 - 永畠秀樹 2006. 炭水化物供給可能量と穂揃期 窒素施肥がイネの白未熟粒の発生に及ぼす影響. 日作紀 75 (別 2)： $12-13$.

中谷治夫 1972. 水稲の栽培条件と収量, 米質に関する研究. 1. 移植時 期が収量・米質におよぼす影響について. 北陸作報 7:1-2.

坂田雅正・高田聖 2006. 高知県における高温登熟による品質低下に
対応する品種と技術開発. 農及園 81 (1) : 102-109.

高田聖 ·坂田雅正 ·亀島雅史 · 山本由徳 - 宮崎彰 2010. 西南暖地の 早期栽培における水稲品種の寡照条件下での高温登熟性の評価法. 日作紀 $79: 142-149$.

高橋涉 · 野村幹雄 ·荒井清完 - 守田和弘 2004. 高温条件下における 乳白, 基白, 背白粒発生に関する研究. 1. 生育初期の高温条件が及 ぼす影響. 日作紀 73 (別 2) : 282-283.

高橋渉 2006. 気候温暖化条件下におけるコシヒカリの白未熟粒発生 軽減技術. 農及園 $81(9): 1012-1018$.

寺島一男 · 齋藤祐幸 · 酒井長雄 ·渡辺富男 - 尾形武文 · 秋田重誠 2001. 1999年の夏期高温が水稲の登熟と米品質に及ぼした影響. 日 作紀 $70: 449-458$.

上田一好 · 楠谷彰人 · 浅沼興一郎 - 一井眞比古 1998a. 香川県におけ る水稲品種キヌヒカリの移植時期に関する研究 - 活着期, 出穂期 および成熟期と気温の関係一. 日作紀 67:136-142.

上田一好 · 楠谷彰人 · 浅沼興一郎 - 一井眞比古 1998b. 香川県に扔け る水稲品種キヌヒカリの移植時期に関する研究一収量および食味 と気象要因との関係一.日作紀 $67: 289-296$.

若松謙一 ·田之頭拓 ·重水剛 ·竹牟禮穣 2004. 鹿児島県早期栽培コ シヒカリの収量構成要素及び食味に対する栽植密度の影響. 日作 九支報 $70: 7-9$.

若松謙一 ·田中明男 ·上薗一郎 ·佐々木修 2006. 水稲の暖地早期栽 培における登熟期間の遮光処理が収量, 品質, 食味に及ぼす影響. 日作九支報 $72: 19-21$.

若松謙一 ·佐々木修 ·上薗一郎 · 田中明男 2008. 水稲登熟期の高温 条件下における背白米の発生に及ぼす窒素施肥量の影響. 日作紀 $77: 424-433$.

若松謙一・佐々木修・田中明男 2009. 暖地水稲における高温登熟条 件下の日射量および湿度が玄米品質に及ぼす影響. 日作紀 $78: 476$ -482 .

山口泰弘・井上健一・湯浅佳織 2004. 高温年次におけるコシヒカリ の移植時期が物質生産・収量・品質に及ぼす影響. 福井農試研報 $41: 29-38$.

Evaluation of the Dense Planting in Late Transplanting Aimed to Avoid High Temperatures During the Ripening Period in Rice Cultivar Koshihikari : Kazuhiro Morita ${ }^{1)}$, Tomoaki Matsushima ${ }^{2)}$, Takuya Yamaguchi ${ }^{1)}$, Ayano Saito ${ }^{3)}$ and Masami Furuhata ${ }^{4)}$ $\left({ }^{1)}\right.$ Toyama Prefectural Agricultural Forestry and Fisheries Research Center, Toyama, 939-8153, Japan; ${ }^{2)}$ Niikawa Agricultural Extension Center; ${ }^{3)}$ Toyama Prefectural Agricultural Technology Division; ${ }^{4)}$ Natl. Agr. Res. Cent. Hokuriku)

Abstract : The effects of dense planting on the growth, yield and grain quality of rice (Oryza sativa L. cv. Koshihikari) late transplanted to avoid a high temperature during the ripening period were investigated for two years. Dense planting, 21.2 and 24.2 hills $/ \mathrm{m}^{2}$, increased the number of panicles resulting in higher yield compared with normal planting, $18.2 \mathrm{hills} / \mathrm{m}^{2} . \mathrm{In}$ addition, it increased the yield in 2008 with slightly solar radiation during the ripening period. Late transplanting with dense planting increased the grain quality in both years, and in addition, improved grain quality in 2007 with much solar radiation during the ripening period. These results suggest that the dense planting in late transplanting is effective in improving yield and grain quality, and also in securing solar radiation while avoiding high temperature during the ripening period.

Key words : Grain quality, High temperature, Koshihikari, Planting density, Rice, Yield. 